\title{
Analisis Pengaruh Profesionalisme, Independensi dan Pengalaman Kerja Pada Kinerja Pengawas Internal (Panureksa) LPD
}

\author{
I Gede Alit Putra ${ }^{1}$ \\ I Ketut Jati ${ }^{2}$ \\ ${ }^{1,2}$ Fakultas Ekonomi dan Bisnis Universitas Udayana (Unud), Bali, Indonesia \\ e-mail:alitputra04@gmail.com
}

\begin{abstract}
ABSTRAK
Penelitian ini bertujuan untuk mengetahui pengaruh profesionalisme, pengalaman dan independensi pada kinerja pangawas internal LPD di Kecamatan Abiansemal Kabupaten Badung. Demi menghasilkan kinerja yang baik diperlukan profesionalisme, pengalaman dan sikap independensi dalam melaksanakan tugas untuk menunjang kinerja pengawas yang baik. Metode penelitian adalah metode kuantitatif, adapun penelitian ini berbentuk asosiatif tipe kausalitas dengan metode pengumpulan datanya menggunakan kuesioner. Populasi dan sampel berjumlah 102 responden dengan metode sampling jenuh. Teknik analisis data adalah analisis regresi linear berganda. Hasil penelitian menunjukkan bahwa profesionalisme, independesi dan pengalaman kerja berpengaruh positif dan signifikan pada kinerja pengawas internal seluruh LPD di Kecamatan Abiansemal. Sehingga sesuai teori peran, dengan dimilikinya pengetahuan dan pengalaman maka akan mengurangi terjadinya konflik peran yang nantinya dapat mempengaruhi kinerja.

Kata Kunci : Profesionalisme, independensi, pengalaman kerja, kinerja pengawas internal
\end{abstract}

\begin{abstract}
This study aims to determine the effect of professionalism, experience and independence on LPD internal supervisory performance in the Abiansemal District of Badung RegencyIn order to produce good performance, professionalism, experience and an attitude of independence are needed in carrying out tasks to support the performance of a good supervisor. The research method is a quantitative method, while this research is an associative type of causality with the method of data collection using a questionnaire. Population and sample amounted to 102 respondents with saturated sampling method. The data analysis technique is multiple linear regression analysis. The results of the study indicate that professionalism, independence and work experience have a positive and significant effect on the performance of internal supervisors of all LPDs in Abiansemal District. So that according to role theory, having knowledge and experience will reduce the occurrence of role conflicts that can later affect performance.

Keywords: Professionalism, independence, work experience, performance internal supervisor
\end{abstract}

\section{PENDAHULUAN}

Untuk menciptakan kesejahteraan rakyat Indonesia yang tengah mengalami

pertumbuhan ekonomi yang tidak stabil, khususnya untuk masyarakat Bali.

Pembentukan Lembaga Keuangan merupakan pilihan yang tepat, karena dapat 
membantu menciptakan dan memberikan bantuan dalam bidang keuangan. Oleh karena itu pemerintah, khususnya di Bali membentuk suatu lembaga keuangan agar dapat membantu perekonomian masyarakat Bali yaitu dengan mendirikan suatu Lembaga Perkreditan Desa (LPD). Peraturan Daerah Provinsi Bali No. 3 Tahun 2017 tentang Lembaga Perkreditan Desa menyatakan bahwa Lembaga Perkreditan Desa (LPD) adalah Lembaga keuangan milik Desa yang bertempat di Desa. Dengan adanya LPD diharapkan masyarakat khususnya masyarakat di Bali mampu untuk meningkatkan kesejahteraan dan mengembangkan usahanya, guna menciptakan masyarakat yang mandiri.

Tujuan keberadaan LPD secara umum adalah untuk menyimpan dan menyalurkan dana kepada krama desa adat lingkup LPD tersebut. LPD memiliki peran yang sangat penting dalam perkembangan perekonomian rakyat pada suatu desa adat yaitu, LPD membantu permodalan usaha kecil dan menengah agar mampu bersaing sehingga dapat meningkatkan taraf hidup mereka serta menyediakan lapangan pekerjaan. LPD merupakan salah satu aset dan sumber pendapatan desa adat sehingga memerlukan pengelolaan yang baik oleh pengurus dan badan pengawas (Putra dan Wisadha, 2012). Perencanaan dan pengendalian yang baik akan sangat membantu dalam pengelolaan LPD. LPD diharapkan untuk melakukan usaha secara efektif agar tetap dapat bersaing, sehingga diperlukan adanya pengawas internal ataupun internal audit.

Sesuai dengan pasal 1 ayat (9) Peraturan Daerah Provinsi Bali No. 3 tahun 2017, yang dimaksuddengan Panureksa (pengawas internal) adalah pengawas internal yang dibentuk oleh Desa Pakraman bertugas melakukan 
pemeriksaan terhadap pengelolaan LPD.Pengawas internal LPD adalah pengendalian intern yang ada di dalam LPD, merupakan aktivitas yang dilakukan oleh orang yang diberikan tugas untuk mengawasi pelaksanaan operasi sesuai dengan hasil pararem atau keputusan desa adat. Khususnya keputusan yang menyangkut organisasi serta tugas lainnya seperti mengawasi dan melakukan pemeriksaan terhadap suatu kebijakan yang disepakati oleh pengurus termasuk menilai efektif tidaknya suatu prosedur dan penyimpanganpenyimpangan yang terjadi pada suatu kebijakan yang telah ditetapkan dan dijalankan oleh pengurus(Putra dan Rasmini, 2014). Oleh Karena itu, pengawas internal LPD memiliki peran yang penting dalam menunjang keberhasilan operasional LPD.

Peran pengawas internal sangatlah penting terutama berkaitan dengan struktur pengendalian intern (Prawitasari dan Badera, 2015). Pengendalian intern merupakan proses yang dijalankan oleh pengawas, pengurus, dan karyawan yang didesain untuk memberikan keyakinan yang memadai tentang pencapaian tujuan, keandalan laporan keuangan, efektivitas dan efisiensi LPD serta kepatuhan terhadap hukum dan peraturan yang berlaku. Desyanti dan Ratnadi (2008), menyatakan bahwa pengawas internal memiliki tanggungjawab penuh dalam melaksanakan tugas pemeriksaan intern. Oleh karena itu, professional seorang pengawas internaldapat dilihat dari kinerja dalam menjalankan tugas dan fungsi dengan baik. Penyimpangan terhadap standar dan prosedur audit dapat memengaruhi kinerja auditor, bahkan dapat menyebabkan kegagalan audit (Donnelly et al 2003). Faktor-faktor yang memengaruhi kinerja 
auditor dapat berupa faktor individu dan lingkungan (Bonner dan Sprinkle, 2002).

Sebagai penunjang keberhasilan dalam menjalankan tugas dan fungsinya, sangatlah diperlukan kinerja auditor yang baik dan berkualitas (Dedik et al, 2014). Kinerja auditor (pengawas) merupakan tindakan atau pelaksanaan tugas pemeriksanaan yang telah diselesaikan oleh auditor dalam kurun waktu tertentu (Trisnaningsih, 2007). Kinerja dapat diukur dengan pengukuran tertentu (standar), yang dimana kualitas berkaitan dengan mutu kerja yang dihasilkan, sedangkan kuantitas adalah jumlah hasil kerja yang dihasilkan dalam kurun waktu tertentu, dan ketepatan waktu adalah kesesuaian waktu yang telah direncanakan, untuk menghasilkan kinerja yang memuaskan seorang pengawas internal harus memiliki sikap yang jujur dan independen yang diterapkan dalam melaporkan hasil pengawasan (Prawitasari dan Badera, 2015). Menurut Kahn et al (1965) teori peran mempengaruhi kinerja pengawas internal, karenateori peran menjelaskan sifat individual sebagai pelaku sosial yang mempelajari perilaku sesuai dengan posisi yangditempatinya di lingkungan kerja dan masyarakat. Oleh karena itu, tugas dan wewenang yang kompleks dari pengawas internal LPD menuntut memiliki eksistensi yang tinggi.

Pentingya eksistensi seorang pengawas internal menuntut seorang
pengawas agar memiliki professionalismedalam menjalankan tugas
pemeriksaannya untuk menghindari terjadinya penyimpangan. Menurut
Hudiwinarsih (2010), sikap profesional sering dinyatakan dalam literatur,


profesionalisme berarti bahwa orang bekerja secara profesional. Profesionalisme merupakan sifat utama yang harus dimiliki oleh seorang auditor. Seorang auditor dituntut memiliki kemampuan dan sikap profesionalisme dalam pelaksanaan audit. Profesionalisme meliputi kemampuan penguasaan baik secara teknis, maupun secara teoritis bidang keilmuan dan keterampilan yang berhubungan dengan tugasnya, sebagai pemeriksa (Asri Usman et al, 2014). Menurut Kusuma (2012) kewajiban dari auditor yang profesional adalah melaksanakan tugas-tugasnya dengan kesungguhan dan kecermatan, sebagai seorang yang profesional, auditor hendaknya terhindar dari sifat tidak jujur dan lalai. Mayasari (2011) menemukan dalam hasil penelitiannya bahwa profesionalisme berpengaruh positif dan signifikan terhadap kinerja auditor.Berbeda dengan hasil penelitian Haris (2015) yang mengemukakan profesionalisme tidak berpengaruh terhadap kinerja auditor.

Sikap independen juga sangat mempengaruhi kinerja pengawas internal dalam menjalankan tugasnya. Auditor harus pula mempunyai sikap independen, sebab hasil audit perusahaan sangat berpengaruh nantinya pada keputusan dari manajeman/ pengurus untuk melanjutkan arah tujuan perusahaan di tahun berikutnya (Mukuru, 2013). Sekalipun ia ahli, apabila tidak mempunyai sikap integritas dan objektivitas dalam mengumpulkan informasi akan tidak berguna, sebab informasi yang digunakan untuk mengambil keputusan haruslah tidak biasa (Windasari dan Juliarsa, 2016). Independensi dalam hal ini adalah independensi dalam pelaporan dimana independensi dalam pelaporan menjadikan auditor internal harus bebas dari perasaan untuk memodifikasi 
dampak dari fakta-fakta, harus bebas dari hambatan oleh pihak-pihak yang ingin meniadakan auditor dalam memberikan pertimbangan. Independensi adalah sikap yang diharapkan dari seorang auditor untuk tidak mempunyai kepentingan pribadi dalam pelaksanaan tugasnya, yang bertentangan dengan prinsip integritas dan obyektivitas (Sekar, 2003). Menurut (Halim, 2008:46) independensi merupakan suatu cerminan sikap dari seorang auditor untuk tidak memilih pihak siapapun dalam melakukan audit. Oleh karena itu seorang auditor ataupun pengawas harus memelihara integritasnya dan objektivitas dalam tugasnya, sehingga kinerja pengawas internal dalam pelaksanaan pengawasannya dapat dilaksanakan secara efektif. Auditor yang menegakkan independensinya, tidak akan terpengaruh dan tidak dipengaruhi oleh berbagai kekuatan yang berasal dari luar diri auditor dalam mempertimbangkan fakta yang dijumpainya dalam pemeriksaan (Triyanthidan Budiartha, 2015).

Selain professionalisme dan independensi pengawas internal LPD harus memiliki pengalaman kerja sebagai seorang pengawas dimana pengalaman ini akan mendukung keterampilan dan kecepatan dalam menyelesaikan tugas, sehingga akan semakin berkurangnya tingkat kesalahan. Semakin tinggi tingkat pengalaman seseorang maka kinerja pengawas internal yang dihasilkan pun akan semakin baik. Hal ini dapat dijadikan rekomendasi bahwa semakin lama masa kerja yang dimiliki oleh seorang auditor, maka akan semakinbaik kualitas hasil pemeriksaan auditor tersebut (Masrizal, 2010). Pengalaman kerja merupakan faktor yang sangat penting dalam memprediksi dan menilai kinerja pengawas internal dalam melakukan pengawasan. Robyndan Peter (2008) 
menemukan bahwa tugas berbasis pengalaman yang diperoleh dalam spesialisasi meningkatkan kinerja industri dalam melaksanakan tugas penilaian saat bekerja di luar daerah spesialisasi mereka.

\section{Tabel 1.}

Perkembangan Dana LPD Se-Kecamatan AbiansemalPer- Desember dari Tahun 2015-2017(dalam ribuan)

\begin{tabular}{lccc}
\hline \multicolumn{1}{c}{ Uraian } & Desember 2015 & $\begin{array}{c}\text { Periode } \\
\text { Desember 2016 }\end{array}$ & Desember 2017 \\
\hline Tabungan & 303.538 .977 & 348.883 .469 & 398.780 .969 \\
Deposito & 355.613 .252 & 451.003 .759 & 558.054 .217 \\
Kredit & 573.068 .325 & 699.569 .849 & 808.051 .539 \\
\hline Sumber:LPLPD Kabupaten Badung, 2018 & &
\end{tabular}

Perkembangan LPD di Kecamatan Abiansemal semakin meningkat setiap tahunnya, seperti pada Tabel 1 menunjukkan peningkatan jumlah dana yang terhimpun dalam LPD Kecamatan Abiansemal setiap periodenya. Akan tetapi secara kualitas masih perlu dilakukan pembinaan yang lebih intensif karena masih ada beberapa LPD yang dinyatakan kurang sehat maupun tidak sehat. Seperti termuat dalam Tabel 2 sebagai berikut:

Tabel 2.

Klasifikasi Kesehatan LPD Se-Kecamatan Abiansemal dari Tahun 20152017

\begin{tabular}{clccc}
\hline Klasifikasi Kesehatan & \multicolumn{3}{c}{ Periode } \\
LPD & $\mathbf{2 0 1 5}$ & $\mathbf{2 0 1 6}$ & $\mathbf{2 0 1 7}$ \\
\hline - & Sehat & 30 & 30 & 25 \\
- & Kukup Sehat & 3 & 1 & 6 \\
- & Tirang Sehat & 1 & 2 & 1 \\
\hline
\end{tabular}

Sumber:LPLPD Kabupaten Badung, 2018

Pada kenyataannya tidak semua bendesa adat yang menjadi ketua pengawas internal LPD juga memahami secara utuh operasional LPD, karena umumnya bendesa adat yang dipilih oleh paruman desa adat adalah orang-orang yang kharismatik, berwibawa, dan hanya memiliki wawasan tentang agama 
(Adi dan Wisadha, 2012) Kondisi tersebutakan mempengaruhi kinerja pengawas internal LPD sebagai auditor internal. Kurangnya kinerja dari pengawas internal melakukan pengendalian intern dalam menjalankan kewajibannya akan mempengaruhi operasional LPD.

Professionalisme didefinisikan sebagaiseorang yang memiliki tingkat keterampilan tertentu dan pengetahuan yang tinggi dalam subjek tertentu yang diperoleh dari pengalaman atau pelatihan. Profesionalnya seorang pengawas internal akan meningkatkan pemahaman individu dengan perannya dan mengurangi konflik peran yang salah satunya tidak mampu-nya individu untuk memahami perannya. Adanya keahlian dan kemampuan dalam melaksanakan pemeriksaan akan dapat lebih mudah mengetahui kekeliruan serta penyimpangan yang merupakan salah satu bagian kompetensi seorang auditor (Febrianty, 2012).

Pengalaman kerja seorang auditor juga akan mendukung keterampilan dan kecepatan dalam menyelesaikan tugas, sehingga akan semakin berkurangnya tingkat kesalahan. Dalam memprediksi kinerja auditor Pengalaman kerja telah dipandang sebagai suatu faktor penting (Davis, 1997). Semakin tinggi tingkat pengalaman seseorang maka hasil pekerjaan yang dihasilkanpun akan semakin bagus. Hal ini dapat dijadikan rekomendasi bahwa semakin lama masa kerja yang dimiliki oleh seorang auditor maka mempengaruhi kualitas hasil pemeriksaan (Masrizal, 2010). Pengalaman kerja merupakan faktor penting dalam memprediksi dan menilai kinerja pengawas 
dalam melakukan pengawasan. Pengalaman kerja akan menambah atau memberikan keahlian profesional bagi pengawas internal.

Pengalaman kerja telah dipandang sebagai faktor penting dalam memprediksi suatu penyimpangan, kelalaian dan kekeliruan oleh auditor (Bonner, 1999). Pengalaman auditor akan semakin berkembang dengan bertambahnya pengalaman audit, diskusi mengenai audit dengan rekan sekerja, pengawas dan review oleh akuntan senior, mengikuti pelatihan dan penggunaan standar auditing. Pengalaman kerja dapat memperdalam dan memperluas kemampuan kerja.

Penelitian Kusnadi (2015) serta (Wulandari dan Dharma (2018) menunjukkan hasil profesionalisme berpengaruh positif dan signifikan terhadap kinerja internalauditor. Selain itu Bamberdan Iyer (2002) serta Cohen dan Single (2001) menunjukkan bahwa profesionalisme berpengaruh positif terhadap kinerja auditor, yang dimana semakin tinggi tingkat profesionalisme auditor maka kinerja yang dihasilkan akan semakin memuaskan. Pengujian terhadap pengaruh profesionalisme pada kinerja yang dilakukan oleh Kalbers dan Forgarty menunjukkan adanya pengaruh positif walaupun hanya pada dimensi afiliasi komunitas dan tuntutan kemandirian Kalbers dan Fogarty, (1995).

Berdasarkan hasil penelitian tersebut di atas, maka dapat diajukan hipotesis sebagai berikut:

$\mathrm{H}_{1}$ : Professionalisme berpengaruh positif dan signifikan pada kinerja pengawas internal. 
Independensi berarti bebas dari pengaruh, tidak dikendalikan oleh pihak lain, dan tidak tergantung kepada pihak lain (Halim, 2008:46). Independensi pada auditor internal dapat berhubungan dengan pengungkapan masalah pengendalian internal suatu perusahaan Zhang Yang et al, (2007).Setiap pengawas harus memelihara integritas dan obyektivitas dalam tugas profesionalnya sesuai dengan role theory (teori peran) yaitu bagaimana sebuah lingkungan organisasi dapat mempengaruhi harapan setiap individu mengenai perilaku peran mereka yang nantinya mempengaruhi independensi pengawas internal. Sikap independensi dirasa sangat penting dalam melaksanakan pengawasan yang efektif. Yadnya dan Dodik (2017) menyatakan independensi berpengaruh pada kinerja pengawas sebagai fungsi internal auditor. Begitu juga Desyanti dan Ratnadi (2008), dalam penelitiannya menunjukkan bahwa independensi berpengaruh positif pada kinerja pengawas. Allen et al, (2005) menyatakan bahwa independensi terbukti berpengaruh positif terhadap kinerja auditor, yang mereka mempersoalkan apabila ada usaha penyelewengan oleh manajemen Allen et al, (2005).

$\mathrm{H}_{2}$ : Independensi berpengaruh positif dan signifikan pada kinerja pengawas internal

Pengalaman kerja seseorang dapat mempengaruhi kualitas hasil pemeriksaan. Semakin tinggi tingkat pengalaman seseorang maka hasil pekerjaan yang dihasilkanpun akan semakin bagus Murtini dan Juliarsa, (2017). Pengalaman kerja sangat mempengaruhi kinerja pengawas agar cepat memahami peran individu di suatu organisasi untuk mengurangi terjadinya ambiguitas peran (role ambiguity). Penelitian yang dilakukan oleh Murtini dan 
Juliarsa (2017) membuktikan bahwa pengalaman kerja badan pengawas berpengaruh positif dan signifikan terhadap kinerja badan pengawas.

Penelitian Saputra dan Gerianta (2013) menghasilkan pengaruh positif dan signifikan secara parsial antara variabel pengalaman kerja terhadap kinerja auditor BPK RI perwakilan provinsi Bali. Selaras dengan penelitian Saputra dan Gerianta hasil penelitianLarkin (2000) yang melakukan penelitian melibatkan internal auditor di lembaga keuangan dan menyatakan bahwa internal auditor berpengalaman cenderung memiliki kinerja lebih konservatif dalam menghadapi suatu situasi.

Berdasarkan hasil penelitian tersebut di atas, maka dapat diajukan hipotesis sebagai berikut:

$\mathrm{H}_{3}$ : Pengalaman kerja berpengaruh positif dan signifikan pada kinerja pengawas internal

\section{METODE PENELITIAN}

Lokasi atau ruang lingkup penelitian ini dilakukan pada LPD se-Kecamatan Abiansemal Kabupaten Badung. Pemilihan lokasi di LPD se-Kecamatan Abiansemal Kabupaten Badung, karena masih cukup banyak ditemukan LPD yang termasuk kategori kurang sehat dan tidak sehat di daerah tersebut dibandingkan LPD di Kecamatan lainnya yang ada di Badung. Sehingga peneliti menggunakan Kecamatan Abiansemal dalam melaksanakan penelitian.

Variabel bebas dalam penelitian ini adalah Profesionalisme $\left(\mathrm{X}_{1}\right)$, Independensi $\left(\mathrm{X}_{2}\right)$ dan Pengalaman Kerja $\left(\mathrm{X}_{3}\right)$. Variabel terikat dalam penelitian ini adalah Kinerja Pengawas (Y). 
Populasi dalam penelitian ini yaitu seluruh pengawas LPD yang ada di Kecamatan Abiansemal, Kabupaten Badung berjumlah 34 LPD, adapun masing-masing LPD terdapat 3 pengawas internal sehingga jumlah populasi adalah102 pengawas internal. Adapun sampel dalam penelitian ini diambil berdasarkan dari jumlah keseluruhan populasi penelitian yaitu 102 orang responden dalam pengisian kuesioner. Metode penentuan sampel dalam penelitian ini berdasarkan metode non probability sampling dengan menggunakan metode sampling jenuh yaitu teknik penentuan sampel bila anggota populasi digunakan sebagai sampel. Jadi jumlah sampel yang digunakan dalam penelitian ini berjumlah 102 responden dari jumlah keseluruhan populasi.

Teknik analisis yang digunakan dalam penelitian ini adalah teknik analisis regresi linear berganda. Analisis Regresi Linear Berganda berfungsi untuk mengetahui pengaruh variabel bebas terhadap variabel terikatnya. Teknik ini menggunakan program Statistical Package for the Social Sciences(SPSS) untuk mengetahui pengaruh profesionalisme, independensi dan pengalaman kerja pada kinerja pengawas internal (panureksa) LPD. Persamaan analisis regresi linear dinyatakan dalam bentuk persamaan regresi linear berganda sebagai berikut:

$\mathrm{Y}=\alpha+\beta_{1} \mathrm{X}_{1}+\beta_{2} \mathrm{X}_{2}+\beta_{3} \mathrm{X}_{3}+\mathrm{e}$

Keterangan:

$\mathrm{Y} \quad=$ Kinerja

$\mathrm{X}_{1,2,3}=$ Profesionalisme, independensi dan pengalaman kerja

$\beta_{1,2,3}=$ Koefisien profesionalisme, independensi dan pengalaman kerja

$\alpha \quad=$ Konstanta

$\mathrm{e} \quad=$ Standar error 


\section{HASIL DAN PEMBAHASAN}

Statistik deskriptif dalam penelitian ini disajikan untuk memberikan informasi mengenai karakteristik variabel-variabel penelitian, antara lain minimum, maksimum, mean, dan standar deviasi. Pengukuran rata-rata (mean) merupakan cara yang paling umum digunakan untuk mengukur nilai sentral dari suatu distribusi data. Sedangkan, standar deviasi merupakan perbedaan nilai data yang diteliti dengan nilai rata-ratanya. Hasil statistik deskriptif dapat dilihat pada Tabel 3 yaitu sebagai berikut

Tabel 3.

Statistik Deskriptif

\begin{tabular}{|c|c|c|c|c|c|}
\hline \multicolumn{6}{|c|}{ Descriptive Statistics } \\
\hline & $\mathrm{N}$ & Minimum & Maximum & Mean & Std. Deviation \\
\hline $\mathrm{X}_{1}$ & 102 & 15 & 28 & 23,19 & 2,974 \\
\hline $\mathrm{X}_{2}$ & 102 & 19 & 36 & 28,47 & 3,266 \\
\hline $\mathrm{X}_{3}$ & 102 & 13 & 24 & 20,15 & 2,507 \\
\hline $\mathrm{Y}$ & 102 & 27 & 52 & 42,84 & 6,085 \\
\hline Valid N (listwise) & 102 & & & & \\
\hline
\end{tabular}

Sumber: Data diolah, 2018

Berdasarkan Tabel 3 dapat dilihat nilai minimum variabel profesionalisme $\left(\mathrm{X}_{1}\right)$ adalah 15 kemudian nilai maksimumnya adalah 28 dan nilai rata-rata untuk profesionalisme $\left(\mathrm{X}_{1}\right)$ adalah 23,19 . Hal ini berarti bahwa berdasarkan hasil statistik deskriptif profesionalisme pengawas internal LPD di KecamatanAbiansemal Kabupaten Badung rata-rata tinggi karena nilai rata-rata lebih mendekati ke nilai maksimum. Standar deviasi 2,97, hal ini berarti bahwa berdasarkan hasil statistik deskriptif terjadi perbedaan nilai profesionalisme yang diteliti terhadap nilai rata-ratanya sebesar 2,97. Hasil analisis deskriptif 
variabel profesionalisme menunjukkan rata-rata terendah terdapat pada pernyataan poin 7 sebesar 3,21, artinya LPD masih perlu untuk meningkatkan pelatihan dan pendidikan professional berkelanjutan untuk pengawas internal demi menunjang kinerja pengawas internal lebih baik dalam melaksanakan pengawasan operasional LPD.

Variabel independensi $\left(\mathrm{X}_{2}\right)$ memiliki nilai minimum sebesar 19, lalu nilai maksimum dari independensi sebesar 36 dan nilai rata-rata sebesar 28,47. Hal ini berarti bahwa berdasarkan hasil dari statistik deskriptif independensi pengawas internal LPD di Kecamatan Abiansemal Kabupaten Badung rata-rata tinggi karena hasil nilai rata-rata independensi lebih mendekati kepada nilai maksimum. Standar deviasi sebesar 3,27, hal ini berarti bahwa berdasarkan hasil statistik deskriptif terjadi perbedaan nilai independensi yang diteliti terhadap nilai rata-rata sebesar 3,27. Hasil analisis deskriptif variabel independensi menunjukkan rata-rata terendah terdapat pada pernyataan poin 2 sebesar 3,06 yang artinya bahwa masih adanya penunjukkan pengawas internal LPD yang memiliki hubungan (keluarga) kepada pimpinan atau pengurus LPD. Pengawas internal yang memiliki hubungan dengan pihak manajemen atau pengurus LPD dapat beresiko mempengaruhi kinerja pengawas internal dalam melaksanakan pengawasan, sehingga LPD harus memperhatikan masalah hubungan dalam menunjuk pengawas internal LPD.

Variabel pengalaman kerja $\left(\mathrm{X}_{3}\right)$ memiliki nilai minimum sebesar 13, lalu nilai maksimum dari independensi sebesar 24 dan nilai rata-rata sebesar 20,15. Hal ini berarti bahwa berdasarkan hasil dari statistik deskriptif 
pengalaman kerja pengawas internal LPD di Kecamatan Abiansemal Kabupaten Badung rata-rata tinggi karena nilai rata-rata lebih mendekati nilai maksimum. Standar deviasi sebesar 2,51, hal ini berarti bahwa berdasarkan hasil statistik deskriptif terjadi perbedaan nilai pengalaman kerja yang diteliti terhadap nilai rata-rata sebesar 2,51.Hasil analisis deskriptif variabel pengalaman kerja menunjukkan rata-rata terendah terdapat pada pernyataan poin 4 sebesar 3,30 artinya bahwa pengawas LPD di Kecamatan Abiansemal masih belum dapat secara maksimal menyelesaikan tugasnya tepat waktu, sehingga diperlukan pelatihan dan pendidikan professional untuk pihak pengawas internal LPD agar menghasilkan kinerja yang lebih baik.

Untuk variabel kinerja (Y) nilai minimumnya adalah 27, nilai maksimumnya 52 dan nilai rata-rata kinerja adalah 42,84. Hal ini berarti bahwa berdasarkan hasil statistik deskriptif kinerja pengawas internal LPD di Kecamatan Abiansemal Kabupaten Badung rata-rata tinggi karena nilai rata-rata lebih mendekati nilai maksimum. Standar deviasi sebesar 6,09, hal ini berarti bahwa berdasarkan hasil statistik deskriptif terjadi perbedaan nilai kinerja yang diteliti terhadap nilai rata-rata sebesar 6,09. Hasil analisis deskriptif variabel kinerja menunjukkan rata-rata terendah terdapat pada pernyataan poin 4 sebesar 3,14 artinya pihak pengawas internal LPD kecamtan abiansemal harus lebih memperhatikan penggunaan biaya agar pengawas internal nantinya tidak membuang-buang biaya yang sebenarnya tidak perlukan. 
Analisis regresi linear berganda digunakan untuk memecahkan rumusan masalah yang ada, yaitu untuk melihat pengaruh antara dua variabel atau lebih. Hasil analisis regresi linear berganda disajikan pada Tabel 4.

\section{Tabel 4.}

Analisis Regresi Linear Berganda

\begin{tabular}{|c|c|c|c|c|c|c|}
\hline & \multirow{2}{*}{ Model } & Unstandardize & Coefficients & $\begin{array}{l}\text { Standardized } \\
\text { Coefficients }\end{array}$ & \multirow[t]{2}{*}{$\mathbf{t}$} & \multirow{2}{*}{ Sig. } \\
\hline & & B & Std. Error & Beta & & \\
\hline \multirow[t]{4}{*}{1} & (Constant) & $-5,292$ & 3,968 & & $-1,334$ & , 185 \\
\hline & $\mathrm{X}_{1}$ &, 719 & ,155 & ,351 & 4,635 & 000 \\
\hline & $\mathrm{X}_{2}$ & ,404 & ,134 & ,217 & 3,023 & ,003 \\
\hline & $X_{3}$ & 991 & ,179 & ,408 & 5,538 &, 000 \\
\hline
\end{tabular}

Berdasarkan Tabel 4 persamaan regresidiatas diperoleh suatu persamaan regresi sebagai berikut.

$$
Y=-5,292+0,719 X_{1}+0,404 X_{2}+0,991 X_{3}+e
$$

Nilai konstanta $(\alpha)$ sebesar -5,292 menyatakan bahwa jika variabel profesionalisme, independensi, dan pengalaman kerja sama dengan nol, maka menunjukkan kinerja pengawas internal akan berkurang.

Koefisien $\left(\beta_{1}\right)$ variabel profesionalisme sebesar 0,719 artinya apabila nilai variabel profesionalisme mengalami kenaikan 1 satuan maka kinerja pengawas internal akan mengalami peningkatan sebesar 0,719 satuan dengan asumsi nilai variabel independen lainnya konstan (tidak berubah). Hasil tersebut menjelaskan bahwa semakin profesional pengawas internal, maka akan meningkatkan kinerja dari pengawas internal dalam melaksanakan pengawasan operasional LPD.

Koefisien $\left(\beta_{2}\right)$ variabel independensi sebesar 0,404 artinya apabila nilai variabel independensi mengalami kenaikan 1 satuan maka kinerja pengawas internal akan mengalami peningkatan sebesar 0,404 satuan dengan asumsi nilai 
variabel independen lainnya konstan (tidak berubah). Hasil tersebut menjelaskan bahwa jika seorang memiliki independensi yang baik, maka hasil kinerja dari pengawas internal tersebut diyakini tidak akan dapat dipangaruhi oleh pihak lain dan dapat dipercaya sebagai bahan pertimbangan.

Koefisien $\left(\beta_{3}\right)$ variabel pengalaman kerja sebesar 0,991 artinya apabila nilai variabel pengalaman kerja mengalami kenaikan 1 satuan maka kinerja pengawas internal akan mengalami peningkatan sebesar 0,991 satuan dengan asumsi nilai variabel independen lainnya konnstan (tidak berubah). Hasil tersebut menjelaskan bahwa dengan mempunyai pengalaman yang cukup, maka pengawas internal akan dapat memahami peran atau tugasnya dengan cepat sehingga akan meningkatkan kinerja yang baik dalam melaksanakan tugas dalam pengawasan operasional LPD.

Untuk melihat apakah data yang digunakan dalam penelitian telah terdistribusi normal dapat dilihat dengan menggunakan uji non parametrik satu sampel Kolmogorov-Smirnov. Hasil uji Kolmogorov-Smirnov dapat dilihat pada Tabel 5 yaitu sebagai berikut.

\section{Tabel 5.}

Hasil Uji Normalitas

\begin{tabular}{llr}
\hline & & $\begin{array}{c}\text { Unstandardized } \\
\text { Residual }\end{array}$ \\
\hline $\mathrm{N}$ & Mean & 102 \\
Normal Parameters ${ }^{\mathrm{a}, \mathrm{b}}$ & Std. Deviation &, 0000000 \\
Most Extreme Differences & Absolute & 3,76478443 \\
& Positive &, 088 \\
Kolmogorov-Smirnov Z & Negative &, 045 \\
Asymp. Sig. (2-tailed) & &,- 088 \\
Sumber:Data diolah, 2018 & &, 892 \\
& &, 404 \\
\hline
\end{tabular}


Berdasarkan Tabel 5, dapat dilihat bahwa unstandarized residu memiliki sebesar 0,404, nilai Asymp.Sig (2-tailed) diatas 0,05. Hal ini berarti seluruh data berdistribusi normal.

Pada Tabel di bawah ini disajikan hasil perhitungan nilai tolerance dan VIF kurang dari angka 10 dan angka tolerance lebih dari 0,1 menggunakan program SPSS.

Tabel 6.

Hasil Uji Multikolinearitas

\begin{tabular}{llcc}
\hline & Model & \multicolumn{2}{c}{ Collinearity Statistics } \\
& Tolerance & VIF \\
\hline 1 & Constant) & & \\
$\mathrm{X}_{1}$ &, 680 & 1,472 \\
$\mathrm{X}_{2}$ &, 759 & 1,317 \\
$\mathrm{X}_{3}$ &, 719 & 1,392 \\
& & &
\end{tabular}

Tabel 6menunjukkan variabel bebas dengan nilai tolerance lebih dari 0,1 atau VIF kurang dari 10, maka dapat dikatakan bahwa model tidak terjadi gejala multikolinearitas.

Hasil uji heteroskedastisitas dapat dilihat pada Tabel 7 yaitu sebagai berikut.

\section{Tabel 7.}

Hasil Uji Heteroskedastisitas

\begin{tabular}{ccc}
\hline Model & Sig. & Keterangan \\
\hline $\mathrm{X}_{1}$ &, 473 & Bebas Heteroskedastisitas \\
$\mathrm{X}_{2}$ &, 341 & Bebas Heteroskedastisitas \\
$\mathrm{X}_{3}$ &, 921 & Bebas Heteroskedastisitas \\
\hline
\end{tabular}

Sumber:Data diolah, 2018

Berdasarkan hasil tersebut dapat dilihat bahwa nilai signifikansi masingmasing variabel di atas $\alpha=0,05$. Jadi, dapat disimpulkan bahwa model regresi tidak mengandung adanya heteroskedastisitas. 
Uji kelayakan model (uji F) dimaksudkan dalam rangka mengetahui apakah dalam penelitian ini model yang digunakan layak untuk digunakan atau tidak sebagai alat analisis untuk menguji pengaruh variabel independen pada variabel dependennya. Hasil pengujian disajikan dalam Tabel 8 sebagai berikut.

Tabel 8.

Hasil Uji Kelayakan Model

\begin{tabular}{|c|c|c|c|c|c|c|}
\hline & Model & $\begin{array}{l}\text { Sum of } \\
\text { Squares }\end{array}$ & df & Mean Square & $\mathbf{F}$ & Sig. \\
\hline \multirow[t]{3}{*}{1} & Regression & 2307,956 & 3 & 769,319 & 52,666 &, $000^{\mathrm{a}}$ \\
\hline & Residual & 1431,534 & 98 & 14,607 & & \\
\hline & Total & 3739,490 & 101 & & & \\
\hline
\end{tabular}

Sumber: Data diolah, 2018

Berdasarkan Tabel 8 dapat dilihat bahwa pada model memiliki nilai sig sebesar 0,00 lebih kecil dari nilai $\alpha=0,05$ menunjukkan model penelitian ini layak untuk digunakan sebagai alat analisis untuk menguji pengaruh variabel independen terhadap variabel dependen. Hal ini dapat dikatakan bahwa variabel profesionalisme, independensi, dan pengalaman kerja berpengaruh secara bersama-sama terhadap variabel dependennya yaitu kinerja.

Analisis koefisien determinasi dilakukan untuk mengukur seberapa besar variabel bebas mampu menjelaskan perubahan variabel terikatnya. Pada penelitian ini koefisien determinasi dilihat melalui nilai $\mathrm{R}^{2}$ yang terlihat pada Tabel 9 sebagai berikut.

Tabel 9.

Hasil Koefisien Determinasi Model

\begin{tabular}{lrrrr}
\hline \multicolumn{1}{c}{ Model } & \multicolumn{1}{c}{ R } & R Square & Adjusted R Square & \multicolumn{2}{c}{$\begin{array}{c}\text { Std. Error of the } \\
\text { Estimate }\end{array}$} \\
\hline 1 &, $786^{\mathrm{a}}$ &, 617 &, 605 & 3,822 \\
\hline Sumber: Data diolah, 2018 & & & &
\end{tabular}

Berdasarkan Tabel 9 dapat dilihat bahwa nilai $\mathrm{R}^{2}$ pada model sebesar 0,617. Nilai $\mathrm{R}^{2}$ Pada model yang artinya $61,7 \%$ perubahan kinerja dapat 
dijelaskan oleh variabel profesionalisme, independensi dan pengalaman kerja. Sedangkan sisanya $(100 \%-61,7 \%=38,3 \%)$ dijelaskan oleh sebab-sebab yang lain diluar model. Standar Error of the Estimate (SEE) sebesr 3,822. Makin kecil nilai SEE akan membuat model regresi semakin tepat dalam memprediksi variabel dependen.

Uji statistik t pada dasarnya dilakukan untuk menunjukkan seberapa jauh pengaruh satu variabel independen secara individual dalam menerangkan variabel variabel dependen. Uji statistik dilakukan dengan membandingkan hasil nilai signifikasi dengan $\alpha=0,05$ dan dapat dijelaskan sebagai berikut.

Tabel 10.

Hasil Analisis Uji Hipotesis (Uji t)

\begin{tabular}{ccccc}
\hline VARIABEL & $\begin{array}{c}\text { Koefisien } \\
\text { Regresi }\end{array}$ & $\mathbf{t}_{\text {hitung }}$ & sig & Hasil Hipotesis \\
\hline Profesionalisme $\left(\mathrm{X}_{1)}\right.$ & 0,719 & 4,635 & 0,000 & $\mathrm{H}_{1}$ diterima \\
Independensi $\left(\mathrm{X}_{2)}\right.$ & 0,404 & 3,023 & 0,000 & $\mathrm{H}_{1}$ diterima \\
Pengalaman kerja $\left(\mathrm{X}_{3)}\right.$ & 0,991 & 5,538 & 0,000 & $\mathrm{H}_{1}$ diterima \\
\hline
\end{tabular}
Sumber: Data diolah, 2018

Berdasarkan Tabel 10 diperoleh nilai signifikasi uji t satu sisi untuk variabel profesionalisme sebesar 0,000 maka tingkat signifikasi t pada uji satu sisi adalah 0,000 lebih kecil dari $\alpha=0,05$ dan nilai koefisien regresi sebesar 0,719 hal ini mengindikasikan bahwa profesionalisme berpengaruh positif dan signifikan pada kinerja sehingga hipotesis pertama dalam penelitian ini diterima.

Berdasarkan Tabel 10 diperoleh nilai signifikasi uji t satu sisi untuk variabel independensi sebesar 0,00 maka tingkat signifikasi t pada uji satu sisi adalah 0,00 lebih kecil dari $\alpha=0,05$ dan nilai koefisien regresi sebesar 0,404 hal 
ini mengindikasikan bahwa independensi berpengaruh positif dan signifikan pada kinerja sehingga hipotesis kedua dalam penelitian ini diterima.

Berdasarkan Tabel 10diperoleh nilai signifikasi uji t satu sisi untuk variabel pengalaman kerja sebesar 0,000 maka tingkat signifikasi t pada uji satu sisi adalah 0,000 lebih kecil dari $\alpha=0,05$ dan nilai koefisien regresi sebesar 0,991 hal ini mengindikasikan bahwa pengalaman kerja berpengaruh positif dan signifikan pada kinerja sehingga hipotesis ketiga dalam penelitian ini diterima.

Berdasarkan hasil penelitian menunjukkan bahwa profesionalisme berpengaruh positif dan signifikan pada kinerja sehingga hipotesis pertama $\left(\mathrm{H}_{1}\right)$ dalam penelitian ini diterima.

Profesionalnya seorang pengawas internal akan meningkatkan pemahaman individu dengan perannya untuk mengurangi terjadinya role ambiguityyang berkaitan dengan kejelasan akan tugas yang harus dikerjakan sesuai dengan deskripsi kerja(Sukarta, 2016). Hasil penelitian ini sejalan dengan hasil penelitian yang dilakukan Kusnadi (2015) serta Wulandaridan Dharma (2018) menunjukkan hasil profesionalisme berpengaruh positif dan signifikan terhadap kinerja internal auditor. Selain itu Bamber dan Iyer (2002) serta Cohen dan Single (2001) menunjukkan bahwa profesionalisme berpengaruh positif terhadap kinerja auditor, yang dimana semakin tinggi tingkat profesionalisme auditor maka kinerja yang dihasilkan akan semakin memuaskan. 
Hasil pengujian hipotesis menyatakan berpengaruh positif dan signifikan pada kinerja. Hasil uji statistik menunjukkan bahwa $\mathrm{H}_{2}$ diterima, artinya variabel independensi berpengaruh positif dan signifikan pada kinerja.

Pengawas internal mengharuskan memiliki integritas dan obyektivitas dalam tugas profesionalnya sesuai dengan role theory (teori peran) yaitu bagaimana sebuah lingkungan organisasi dapat mempengaruhi harapan setiap individu mengenai perilaku peran mereka yang nantinya mempengaruhi independensi pengawas internal. Hasil penelitian ini sejalan dengan Yadnya dan Dodik (2017) menyatakan independensi berpengaruh positif dan signifikan pada kinerja pengawas sebagai fungsi internal auditor. Begitu juga (Desyanti dan Ratnadi 2008)dalam penelitiannya menunjukkan bahwa independensi berpengaruh positif pada kinerja pengawas, serta didukung dengan penelitian Allen et. al (2005) menyatakan bahwa independensi terbukti berpengaruh positif terhadap kinerja auditor, yang mereka mempersoalkan apabila ada usaha penyelewengan oleh manajemen.

Hasil pengujian hipotesis menyatakan pegalaman kerja berpengaruh positif dan signifikan pada kinerja. Hasil uji statistik menunjukkan bahwa $\mathrm{H}_{3}$ diterima, hal ini menunjukkan bahwa variabel pengalaman kerja berpengaruh positif dan signifikan pada kinerja.

Penelitian ini sesuai dengan teori peran dimana dengan memiliki pengalaman kerja akan mempengaruhi kinerja pengawas dalam memahami peran individu di suatu organisasi untuk mengurangi terjadinya ambiguitas peran (role ambiguity). Hasil dari penelitian yang dilakukan oleh Murtini dan 
Juliarsa (2017) membuktikan bahwa pengalaman kerja pengawas berpengaruh positif dan signifikan terhadap kinerja badan pengawas. Selaras dengan hasil penelitian Murtini, hasil penelitian Saputra dan Gerianta (2013) menghasilkan pengaruh positif dan signifikan secara parsial antara variabel pengalaman kerja terhadap kinerja auditor BPK RI perwakilan provinsi Bali.

Penelitian ini diharapkan dapat memberikan kontribusi mengenai teori peran (role theory) dalam menjelaskan hubungan pengaruh profesionalisme, independensi dan juga pengalaman kerja pengawas dalam melaksanakan kinerja pengawasan di LPD. Hasil uji dalam penelitian ini menemukan bahwa ketiga variabel independen yakni profesionalisme, independensi dan pengalaman kerja berpengaruh positif dan signifikan pada kinerja pengawas internal (panureksa).

Dari hasil penelitian ini mendukung teori peran yakni dengan profesionalisme, independensi dan pengalaman kerja maka akan mengurangi terjadinya role ambiguityyang merupakan kondisi stress yang di sebabkan oleh kebingungan karena ekspektasi peran tidakdipahami secara jelas dan tidak adanya informasi serta pengetahuan memadai yang diperlukanseseorang untuk memenuhi peran mereka secara memuaskan. Sehingga semakin tinggi profesionalisme, independensi dan pengalaman kerja pengawas maka akan meningkatkan kinerja pengawas internal dalam melaksanakan perannya sebagai pengawas operasional LPD.

Hasil penelitian ini memberikan kontribusi positif bagi semua pihak khususnya pihak pengawas internal (panureksa) dan LPD itu sendiri. Bagi pihak pengawas internal hendak bersungguh-sungguh dalam menjalankan tugasnya 
sesuai dengan peran yang telah diberikan dan bekerja sesuai SOP badan pengawas internal LPD. Karena dalam melaksanakan pengawasan pengawas internal harus melakukan tugasnya secara professional dan bebas dari tekanan, untuk menunjang kinerja pengawas internal yang lebih baik dan menghasilkan operasional LPD yang sehat dan sesuai dengan hasil dari peruman desa adat yang telah ditetapkan.

Bagi pihak LPD dalam melaksanakan pemilihan badan internal harus memilih orang-orang yang memang memiliki pengalaman atau profesi sebagai pengawas ataupun auditor. Karena dari tabulasi data hasil penelitian masih cukup banyak pendidikan dari pengawas internal LPD hanya lulusan SMA yaitu berjumlah 45 orang dan juga hanya SMP 5 orang. Itu menandakan bahwa pengawas internal LPD masih kurang professional atau kurang memiliki kemampuan dalam melaksanakan pengawasan. Jadi pihak LPD harus lebih selektif dalam memilih pengawas internal dan juga lebih sering untuk melaksanakan pelatihan pengawas internal, agar dapat meningkatkan kemampuan dan pengalaman dari pengawas internal dalam melaksanakan tugasnya. Bagi penelitian selanjutnya, penelitian ini diharapkan dapat menjadi bahan rujukan untuk menambah informasi yang diperlukan dan sebagai acuan dalam penelitian yang dilakukan.

\section{SIMPULAN}

Profesionalisme berpengaruh positif dan signifikan pada kinerja pengawas internal LPD di Kecamatan Abiansemal Kabupaten Badung. Hasil ini berarti 
bahwa semakin professional pengawas internal LPD maka akan semakin meningkat pula kinerja pengawas internal dalam melaksanakan pengawasan.

Independensi berpengaruh positif dan signifikan pada kinerja pengawas internal LPD di Kecamatan Abiansemal Kabupaten Badung. Hal ini menjelaskan bahwa semakin independen pengawas internal LPD maka akan semakin meningkatan kinerja pengawas internal dalam melaksanakan pengawasan.

Pengalaman kerja berpengaruh positif dan signifikan pada kinerja pengawas internal LPD di Kecamatan Abiansemal Kabupaten Badung. Hasil ini berarti bahwa semakin banyaknya pengalaman seorang pengawas internal LPD dalam melaksankan pengawasan maka akan meningkatkan pula kinerja pengawas internal dalam melaksanakan pengawasan operasional LPD.

Diharapkan agar LPD dapat memilih anggota badan pengawas internal yang memiliki profesi atau keahlian dibidang pengawasan atau audit dan memiliki pengalaman yang cukup dalam melaksanakan pengawasan agar menghasilkan kinerja operasional LPD yang lebih baik. Karena dari hasil tabulasi data, masih banyak pengawas internal LPD yang pendidikan terakhirnya adalah SMA dan masih ditemukan hanya lulusan SMP. LPD juga harus lebih memfalisitasi pengawas dalam mengikuti pendidikan professional berkelanjutan misalnya lebih rutin mengadakan pelatihan, karena poin 7 professionalisme dalam kuesioner nilai totalnya paling rendah dari poin lainnya. Sehingga LPD harus lebih memperhatikan pelatihan atau pendidikan pengawas internal LPD. Selain itu juga, untuk meningkatkan independensi pengawas 
internal, masyarakat desa adat dan pengurus LPD harusnya memilih pengawas internal yang tidak memiliki hubungan (keluarga) dengan pimpinan LPD. Karena jika memiliki hubungan mungkin saja pengawas internal dan pimpinan LPD akan berkerjasama melakukan kecurangan untuk kepentingan pribadi, dan itu akna mempengaruhi operasional LPD.

Diharapkan agar badan pengawas internal lebih meningkatkan keahlian profesionalnya dan pengalaman kerjanya dengan lebih banyak mengikuti pelatihan yang biasanya diadakan pihak LPD, kecamatan ataupun kabupaten serta dalam bekerja melaksanakan dengan obyektif atau harus memiliki independensi yang tidak terpengaruh oleh ikatan atau hubungan tertentu dalam melaksanakan pengawasan. Pengawas internal LPD harus lebih aktif dan rutin melaksanakan pengawasan operasional seperti apa yang tercantum dalam SOP pengawas internal LPD, karena masih adanya temuan pengawas internal LPD yang jarang hadir atau melaksanakan tugasnya.

Hasil penelitian ini diharapkan dapat memberkan kontribusi dan tambahan pengetahuan dalam pengembangan teori-teori yang sesuai dengan penelitian yang dilakukan. Berdasarkan hasil Adjusted R Square yang menunjukkan jumlah sebesar 0,617 atau $61,7 \%$ variasi pada kinerja pengawas internal dipengaruhi oleh profesionalisme, independensi dan pengalaman kerja. Sementara sisanya $38,3 \%$ variasi pada variabel kinerja pengawas internal dipengaruhi oleh variabel lain yang tidak diteliti dalam penelitian ini. Penelitian selanjutnya diharapkan dapat menambahkan variabel lainnya yang berkaitan dengan kinerja pengawas internal dari sisa yang berjumlah 38,3\% tersebut. 


\section{REFERENSI}

Adi, I. G., Putra, D., dan Wisadha, I. G. S. (2012). Pengalaman Auditor Pada Kualitas Audit Badan Pengawas Lembaga Perkreditan Desa ( Lpd ), 8998.

Allen, Mary F., Linville, M., and Stott, D., M. (2005). The Effect of Litigation on Independent Auditor Selection. American Journal of Business, 20(1), 37.

Asri Usman, Made Sudarma, Hamid Habbe, and Darwis Said. (2014). Effect of Competence Factor, Independence and Attitude against Professional Auditor Audit Quality Improve Performance in Inspectorate (Inspectorate Empirical Study in South Sulawesi Province). Journal of Business and Management,16(1), 1-13.

Bamber, E. Michael dan Iyer Venkataraman M. (2002). Big 5 auditors' professional and organizational identification: Consistency or conflict. A Journal Practice and Theory Volume, 20(2), 21.

Bonner, S. E. (1999). Judgment and decision-making research in accounting. Accounting Horizons, 44, 125-164.

Bonner, S. E., and Sprinkle, G. B. (2002). The effects of monetary incentives on effort and task performance: theories, evidence, and a framework for research. Accountine, Organizations and Society, 27, 303-345.

Cohen, J. R. dan Single Louise E. (2001). An Examination Of The Perceived Impact Of Flexible Work Arrangements Professional Opportunities In Public Accounting. Journal of Business Ethics., 32(4), 317.

Davis, C. E. (1997). Experience And the Organization of Auditors Knowledge. Managerial Auditing Journal, 12(8), 411-422.

Dedik, Suariana, Nyoman Trisna Herawati, dan Ari Surya Darmawan. (2014). Pengaruh Gaya Kepemimpinan dan Independensi terhadap Kinerja Auditor Eksternal (Studi Kasus pada Kantor Akuntan Publik di Provinsi Bali). Jurnal Akuntansi, 2(1), 1-10.

Desyanti, Ni Putu Eka dan Ni Made Dwi Ratnadi. (2008). Pengaruh Independensi, Keahlian Profesional, dan Pengalaman Kerja Pengawas Intern Terhadap Efektivitas Penerapan Struktur Pengendalian Intern Pada Bank Perkreditan Rakyat di Kabupaten Badung. Jurnal Akuntansi Dan Bisnis, 3(1), 34-44. 
Donnelly, D. P., Quirin, J. J., \& O’Bryan, D. (2003). Auditor Acceptance of Dysfunctional Audit Behavior: An Explanatory Model Using Auditors Personal Characteristics. Behavioral Research in Accounting.

Febrianty. (2012). Pengaruh Profesionalisme Auditor terhadap pertimbangan tingkat materialitas Audit Atas Laporan Keuangan. Jurnal Ekonomi Dan Informasi Akuntansi., 2(2), 159-200.

Halim, A. (2008). Auditing I. Dasar-dasar Audit Laporan Keuangan. Edisi Ketiga. Yogyakarta: UPP STIM YKPN.

Haris, Fuad. (2015). Pengaruh Pengalaman, Otonomi, Profesionalisme, Ambiguitas Peran, Dan Motivasi Tehadap Kinerja Auditor. Jurnal Ekonomi Dan Informasi Akuntansi., 2(1), 48.

Hudiwinarsih, G. (2010). Auditors'Experience, Competency, And Their Independency As The Influencial Factors In Professionalism. Journal of Economics. Business and Accountancy Ventura Volume, 13(3), 253-264.

Kahn. R.L, D.M. Wolf, R.P. Quinn, J. D. S. and R. A. R. (1965). Organizational Stress: Studies in Role Conflict and Ambiguity. American Journal of Sociology, 71(1), 103-104.

Kalbers, L. P., \& Fogarty, T. J. (1995). Professionalism and Its Consequences: A Study of Internal Auditors. Auditing: A Journal of Practice \& Theory, 14(1), 64-86.

Kusnadi, I Made Gheby. (2015). Pengaruh Profesionalisme dan Locus Of Control terhadap Kinerja Auditor di Kantor Akuntan Publik Provinsi Bali. E-Jurnal Akuntansi Universitas Udayana, 13(1), 276-291.

Kusuma, Novanda Friska Bayu Aji. (2012). Pengaruh Profesionalisme Auditor, Etika Profesi Dan pengalaman Auditor Terhadap Pertimbangan Tingkat Materialitas. Skripsi Fakultas Ekonomi Universitas Negeri Yogyakarta.

Larkin, J. M. (2000). The Ability of Internal Auditors to Identify Ethical Dilemmas. Journal of Business Ethics, 23(4), 401-409.

Masrizal. (2010). Pengaruh Pengalaman dan Pengetahuan Audit terhadap Pendeteksian Temuan Kerugian Daerah (Studi Pada Auditor Inspektorat Aceh). Jurnal Telaah Dan Riset Akuntansi, 3(2), 173-194.

Mayasari, Dian. (2011). Pengaruh Profesionalisme, Independensi, Kompetensi, Etika profesi, dan Pengetahuan auditor dalam mendeteksi kekeliruan terhadap ketepatan pembelian opini audit oleh auditor. Karya ilmiah. UIN 
Syarif Hidayatullah Jakarta.

Mukuru, E. dan K. (2013). Effect of Motivation on Employee Performance In Public Middle Level Technical Training Institutions In Kenya. International Journal of Advances in Managemen and Economics., 2(8), 73-82.

Murtini, N. N. dan J. (2017). Pengaruh Independensi, Keahlian Profesional, Pengalaman Kerja dan Tingkat Pendidikan pada Kinerja Pengawas Koperasi. E-Jurnal Akutansi Universitas Udayana, 20(2), 256.

Peraturan Gubernur Bali No. 44 /2017 tentang Peraturan Pelaksanaan Peraturan Daerah Provinsi Bali Nomor 3 Tahun 2017 Tentang Lembaga Perkreditan Desa. 21 Juli 2017. Berita Daerah Provinsi Bali Tahun 2017 Nomor 44. Bali.

Prawitasari, Putu Putri dan I Dewa Nyoman Badera. (2015). Pengaruh Independensi, Keahlian Profesional, dan Pengalaman Kerja Pada Kinerja Pengawas Koperasi Serba Usaha Di Kecamatan Denpasar Timur. Jurnal Akuntansi, 11(1), 15-28.

Putra, I. G. A. dan I. G. Wisadha S. (2012). Pengalaman Auditor pada Kualitas Audit Badan Pengawas Lembaga Perkreditan Desa (LPD). Jurnal Ilmiah Akuntansi Dan Bisnis., 8(2), 89-98.

Putra, Putu Bayu Sadhana dan Ni Ketut Rasmini. (2014). Pengaruh Independensi, Kompetensi, dan Ruang Lingkup Pekerjaan Audit Pengawas pada Efektivitas Pengendalian Intern Koperasi. E-Jurnal Akuntansi, 8(3), 371-384.

Robyn, A. Monorey dan Peter. (2008). Industry Versus Task-Based Experience Auditor Perfomance. A Journal of Practice \& Theory, 30(2), 1-18.

Saputra, Gede Widya dan Gerianta Wirawan Yasa. (2013). Pengaruh Independensi, Profesionalisme, Tingkat Pendidikan dan Pengalaman Kerja pada Kinerja Auditor. E-Jurnal Akuntansi, 2(2), 488-503.

Sekar, Mayang Sari. (2003). Pengaruh Keahlian Audit dan Independensi pada Pendapat Audit: Sebuah Eksperimen. Jurnal Riset Akuntansi Indonesia., 4(1), 79-89.

Sukarta, Made Andy Pradana. (2016). Pengaruh Role Conflict, Role Ambiguity, Role Overload dan Job Insecurity pada Burnout Konsultan Pajak Di Kantor Konsultan Pajak Se-Provinsi Bali. Tesis. Universitas Udayana.

Trisnaningsih, Sri. (2007). Independensi auditor dan komitmen organisasi 
sebagai mediasi pengaruh pemahaman Good Governance, Gaya Kepemimpinan dan Budaya Organisasi terhadap Kinerja Auditor. Simposium Nasional Akuntansi X, 1-56.

Triyanthi, Meylinda dan I K. B. (2015). Pengaruh Profesionalisme, Etika Profesi, Independensi, Dan Motivasi Kerja Pada Kinerja Internal Auditor. E-Jurnal Akutansi Universitas Udayana., 10(3), 797-809.

Windasari, Made Yunita dan Gede Juliarsa. (2016). Pengaruh Kompetensi, Independensi, Dan Profesionalisme Auditor Internal Dalam Mencegah Kecurangan pada BPR Di Kabupaten Badung. E-Jurnal Akuntansi Universitas Udayana., 17(3), 1924-1952.

Wulandari, A. A. Sayu Gita dan I Dewa GdeDharma Suputra. (2018). Pengaruh Profesionalisme Auditor, Komitmen Organisasi dan Etika Profesi Pada Kinerja Auditor KAP Provinsi Bali. E-Jurnal Akutansi Universitas Udayana., 17(3), 1924-1952.

Yadnya, I Putu Parta dan Dodik Ariyanto. (2017). Pengaruh Kompetensi dan Independensi pada Kinerja Auditor dengan Etika Auditor Sebagai Variabel Moderasi. E-Jurnal Akuntansi Universitas Udayana., 192(2), 973-999.

Zhang Yang, Jian Zhou, and N. Z. (2007). Audit Committee Quality, Auditor Independence, And Internal Control Weaknesses. Journal of Accounting and Public Policy, 26, 300-327. 